\title{
E2F3 Gene Amplification
}

National Cancer Institute

\section{Source}

National Cancer Institute. E2F3 Gene Amplification. NCI Thesaurus. Code C158110.

A molecular genetic abnormality indicating the presence of multiple copies of the E2F3 gene. 